\title{
A Tribute to the Japanese Literature of Korean Writers in Japan
}

\author{
Elise Foxworth \\ The University of Melbourne
}

\section{Introduction}

As a recipient of a Japan Foundation Fellowship in 2000, I was able to commence doctoral studies on the little-known Japanese literature of zainichi Koreans in Japan. The term 'zainichi Korean', as opposed to 'newcomer Korean', refers to Koreans and their descendants whose presence in Japan is a direct result of Japan's thirty-five year occupation of the Korean Peninsula, which began in 1910. My overarching goal was to achieve a nuanced understanding of postwar Japanese society, one that encompassed zainichi Korean perspectives, which are generally overlooked by mainstream studies. Although I had studied Japanese society for over six years, held a Masters Degree in Japanese studies and had lived in Japan for five years, I nevertheless had had minimal exposure to minority culture in Japan. While lecturing in Japanese studies in Australia I became increasingly aware of a dearth of scholarship on Japan's minorities in English-language textbooks, in both Japanese studies and post-colonial studies. I felt that if I were to continue to identify myself as a Japan specialist, and if I wanted to truly provide Australian tertiary students with accurate instruction in the complexities of Japanese society, I needed a more comprehensive understanding of postwar Japan. How, I began to wonder, did marginalised Koreans 'understand' postwar Japan and, more importantly, how did they articulate this in artistic or cultural forms? I decided to use zainichi Korean literary narratives as a lens through which to gain greater insight into Japanese society.

\section{Overview}

Zainichi Korean literature is, by definition, written by zainichi Koreans about zainichi Korean issues. Zainichi Korean literature takes up Japanese colonialism, post-colonial oppression in Japan, the Korean War, American imperialism, Korean political affairs, ethnicity, nationalism and inter- and intra-generational struggles. The project of much of zainichi Korean writing is not only to make racial oppression visible, but also to depict its effects on the subjectivity of its subjects. Historical, sociological, and political works written about zainichi Koreans do not necessarily tell of the lived experience of racism, nor do they facilitate a subtle or nuanced understanding of how racial oppression affects the individual. Creative fiction, on the other hand, offers meaningful insights into how racism feels, and invites the reader to identify with its subjects to a greater extent than other types of discourse. 
Novels by 'first-generation' zainichi Korean writers such as Kim Sa Ryang and Kim Tal Su invariably take up the issues of Japanese colonialism, American imperialism, the Korean War, unification and a recovery of 'Korean-ness'. Their themes are similar to those of other nationalist writers in newly independent countries in the early postwar era. Novels by second-generation writers such as Lee Hoe Sung, Kim Ha Gyong and Lee Yang Ji, by contrast, generally focus on poverty, unemployment and racism in early postwar Japan; domestic violence, the sense of alienation zainichi Koreans tend to feel in Japan or Korea and the painful process of self-determination. Finally, third- and fourthgeneration writers such as Yū Miri, Gen Getsu and Kaneshiro Kazuki tend to take up a diversity of issues in their novels. ${ }^{1}$ While their literature is unmistakably informed by the political, cultural and familial implications of what it means to be a zainichi Korean in Japanese society, there is some debate as to the legitimacy of labelling it as 'zainichi Korean' literature. This is partly because of a seeming lack of attention to issues of 'ethnicity' and related political concerns in their literature, but also because of debates surrounding the significance of categorising writers by their ethnicity and concerns as to the degree such categorisation either further 'minoritises' or 'exoticises' those writers. ${ }^{2}$

My doctoral thesis takes as its project an analysis of how identity issues are textualised in six semi-autobiographical novels of three second-generation writers, Kim Sok Pom, Lee Hoe Sung, and Kim Ha Gyong. These six novels highlight the various approaches to self-representation and identity formation adopted by second-generation zainichi Koreans, between the 1950s and 1970s. The three writers had radically dissimilar histories, so they articulate an enormous variety of cultural, historical and linguistic knowledge and experience. Their narratives thus destabilise Japanese stereotypes that veil the diversity of second-generation zainichi Koreans born before 1945, and offer markedly different views on ethnicity and national identity. Though they articulate the concept of identity in different ways in their fiction, their prose nevertheless reveals that identity fragmentation - the problem of negotiating incongruous, hybrid Japanese and Korean identities - was, in fact, a critical experience for second-generation zainichi Koreans of their era. The destabilisation of Korean identities, a result of Japanese colonial and post-colonial projects of disenfranchisement and racism, permeates and shapes their literature. The three writers not only provide gripping accounts of humanity, but also pose highly philosophical questions of existence; and give counsel on self-determination through their strategic uses of plot, characterisation, allegory, metaphor and a rich distinctive use of the Japanese language.

While ethnicity and national identity are major concerns of the writers, there is no single consistent national identity that can be considered representative for secondgeneration zainichi Koreans or for the Korean diaspora at large, despite common assumptions to the contrary. The three writers voice both essentialist and non-

\footnotetext{
${ }^{1}$ Yũ is technically second-generation but considered third-generation.

${ }^{2}$ There is a growing interest in zainichi Korean literature and existing critiques by scholars, such as Takeda Seiji, Kawamura Minato and Melissa Wender, are evaluated in my thesis.
} 
essentialist positions at different moments, and dispel simplistic stereotypic views about second-generation zainichi Koreans in Japan. In this article, I briefly introduce some of the key themes the three writers raise in their literature at large and then provide an abstract and brief analysis of one of each of their novels.

\section{Themes of Kim Sok Pom's Oeuvre}

Born in Japan in 1925, Kim writes about the experiences of Koreans living on the southern Korean island of Cheju, during the 1948-1949 Cheju Insurgency. The insurgency commenced on 3 April 1948, when Cheju Islanders took up arms against American imperialism in Korea, and in particular to challenge American-inspired South-only elections to be held the following month. The U.S. Military and South Korean militias responded by torturing and killing communists and suspected sympathisers, killing 80,000 islanders out of a total of 200,000. Over 40,000 islanders fled to Japan, giving rise to a distinctive group of zainichi Koreans for whom Kim is a celebrated voice. Key themes in Kim's literature include imperialism, notions of home, survival and popular nationalism. Kim questions the choices people have vis-à-vis their identity in a context of state violence and decay. Kim's depiction of state genocide illustrates how the problem of state and political hegemony affects identity politics. Kim's heroes find agency through political espionage, organised crime, shamanism and nostalgia for the motherland.

\section{Kim Sok Pom's 「鴉の死」Karasu no shi [The Death of the Crow $]^{3}$}

Set in the winter of 1949, just half a year after the massacre, Kim's 1957 The Death of the Crow traces the movements and thoughts of a young Korean spy, Jong Ki Jun. Ki Jun's story and the structure of the novel mirror the geopolitical position of the island. Situated at the crossroads of China, the USSR, Japan and Korea, Cheju is caught between several powerful forces. The story highlights how hundreds of thousands of people lost their lives as a result of the Korean War, and how the political and existential landscape was irrevocably changed in the short period from 1945 to 1950. Around the hero Kim introduces a number of other characters, who stand for the principal players on the Korean stage after Japan's defeat and the lead up to the Korean War. Communism, capitalism, the masses and traditional Mother Korea are all allegorised in three-dimensional characters; however, Jong Ki Jun is the individual caught in the middle of the antithetical forces they symbolise, and as such, is evocative of a zainichi Korean identity. The trajectory of events in The Death of the Crow follows suit. The novel highlights how Ki Jun, as a spy, finds himself caught in an uneasy intermediary position between the various political and ideological convictions that are fuelling the conflict, and depicts how he ultimately

${ }^{3}$ All translations of titles and passages are my own. 
comes to terms with the exigencies of his own disjointed circumstances. ${ }^{4}$

The poignancy and power of the novel lies in its penetrating and expert depiction of the spy, caught between two worlds and his emotional reconciliation to this state of being. Ki Jun regularly agonises over his position, grieving that historical circumstances have forced him to live a lie, forced him to be someone he is not, and forced him to hide his anti-American or communist feelings and identity. His situation is clearly an allegory of zainichi Koreans who must pretend to be Japanese to survive in Japanese society. Ki Jun's position is one in which he is marginal to both 'right' and 'left' political cultures; a metaphor for the marginal position of the zainichi Korean vis-à-vis both Japanese and Korean cultures.

In the climatic denouement of the novel, after witnessing his lover's execution $\mathrm{Ki}$ Jun shoots a crow sitting atop the corpse of another girl, a decidedly symbolic act that inspires the title of the novel. Then, in a seemingly senseless act, he turns and shoots two bullets into the body of the girl:

Ki Jun took one step forward... and fired into the girl's chest... 'Thank God, he thought instinctively. Then he walked away. Everything was over. Everything was starting anew. All at once Ki Jun smiled broadly... He put his foot firmly down... The sky was monumental. Under that sky on Shinjanno road carts were rolling by, children were running, women were carrying baskets on their backs. None of this felt remote anymore... He knew that he must live (Kim, S. P.: 140-1).

The final act of killing the crow and shooting the girl's body allegorises Ki Jun's severance of his emotional link to his lover, to Korea, to his past and colonial recollections, and to an era that he can no longer retrieve; that is, a pre-colonial way of life. It thus ensures his own survival and powerfully signals his decision to accept his existence as a spy, a metaphor for the zainichi Korean. Ki Jun emerges a successful spy or zainichi Korean, committed to an independent subjectivity of his own. The Death of the Crow, then, is a metaphor for Ki Jun's emotional metamorphosis and acceptance of who he is and his intermediary position in the world.

\section{Themes of Lee Hoe Sung's Oeuvre}

Lee's early novels are heart-rending portraits of family strife, discrimination and internal conflict, all of which accurately characterise zainichi Korean life in Japan between the 1940s and 1960s. After winning the prestigious Japanese Akutagawa Prize for Belles-

\footnotetext{
${ }^{4}$ See a discussion of this notion of 'different modes of existence emerging in the juxtaposition of the different ideological beliefs and personal experiences of characters' with regard to the Negritude writers mentioned in Boehemer Colonial and Postcolonial Literature, p. 115 .
} 
Lettres for The Cloth Fuller in 1972, Lee Hoe Sung became the first zainichi Korean writer to achieve a degree of recognition by the Japanese public at large. Lee writes about Koreans who, like himself, came to Japan from Karafuto (Sakhalin) in the late 1940s after a period of forced residence there under Japanese colonial rule. Despite strong desires to return home, the looming Korean War prevented their repatriation to Korea and so an intended temporary residence was set up in an inhospitable Japan. Lee's early novels depict the struggles of second-generation zainichi Koreans growing up in a racist Japan, in Korean homes with violent first-generation fathers. His literature brought him recognition amongst zainichi Koreans as a consummate 'second-generation' writer. His zainichi Korean peers hailed his paradigmatic sketch of the process of identity formation from Japanese to half-Japanese/half-Korean to Korean - as an accurate description of their process of self-determination. ${ }^{5}$ Key themes in his early literature include the ideologies of Imperial Fascism (servitude to the Japanese Emperor), postwar democracy, and Korean nationalism and their influence on the identity formation and self-determination of second-generation zainichi Koreans in Japan.

\section{Lee Hoe Sung's 「砧をうつ女」Kinuta wo utsu onna [The Cloth Fuller] ${ }^{6}$}

The Cloth Fuller depicts the life of a young woman, Jang Suri, until her untimely death at the age of thirty-three, as remembered by her third son, Jojo. With The Cloth Fuller, Lee put his own childhood and mother's life story into print. The story is delivered partly through the grandmother's account of their family life in Korea, which helps to engender for the boy, and by extension for all zainichi Koreans, a sense of a Korean identity. By featuring the grandmother's sinse taryong - a Korean tradition of memorialising the struggles of life in rhythmic monologue-song form - Lee advocates looking to firstgeneration Koreans for cultural knowledge. Through hearing the sinse taryong the boy gains a positive sense of himself and his mother as well as knowledge of his people's history.

In her sinse t'aryong, the grandmother expresses her grief at Jang Suri's departure for Japan in the colonial era. 'Suri had married a Korean coal miner, who was taking her to the northernmost tip of Japan, the outpost of Karafuto. Her parents simply could not conceive of where that Karafuto might be' (Lee: 206). The geographic and emotional distance between Korea and Japan that Lee evokes works to veto Japan's territorial claim to Korea and Sakhalin:

Is it fate? Is it the result of Korea's devastation? Why would she want to go to that country of thieves? Wasn't it enough that they stole our land? Why did they have to steal our

\footnotetext{
${ }^{5}$ For an in-depth discussion of this see Takeda, [Zainichi] toiu Konkyo.

${ }^{6}$ Dr. Barbara Nelson provides a good translation of the novel, cf: Nelson in McCann, Black Crane, pp. 92-136. For this reason all the words in the title are capitalised and the title is placed in parentheses, not square brackets, as dictated by the Harvard Journal of Asiatic Studies Style Sheet. The translations in this paper, however, are mine. Indeed the title of the novel is translated by Dr. Nelson as 'The woman who ironed clothes.' However, I prefer my translation, The cloth fuller, for the title.
} 
daughter too? Oh what a fate. Oh Suri (Lee: 206).

Throughout the text Lee takes pains to depict Suri, the family and their familial experiences as distinctly Korean. His use of Korean symbols and imagery also paradoxically discloses the mechanics of the forces of assimilation. In this way, his work may be viewed as an antidote to the state-sponsored Japanisation of zainichi Koreans, so prevalent during both the colonial period and the time of writing the novel. The Cloth Fuller finishes where it starts, with Jang Suri's death. Holding her husband's hand, she encourages him to be still and live with pride as the Korean man he is (Lee: 227). Ultimately, The Cloth Fuller functions as a valuable historical resource for zainichi Koreans to awaken an awareness of their Korean roots and to heighten a sense of Korean identity.

\section{Themes of Kim Ha Gyong's Oeuvre}

In 1985 writer Kim Ha Gyong tragically committed suicide at the age of forty-six. Kim's life, death and literature were influenced by three facts: he had a severe stutter, he had a violent father and he was a zainichi Korean. Kim never achieved the degree of fame that Kim Sok Pom or Lee Hoe Sung did, but his novels provide both a compelling picture of life for Koreans in Japan in the 1950s and 1960s, and until then unprecedented views on ethnicity and identity. Kim's stutter put him on the margins of society in ways being a Korean did not, and this had a huge bearing on his analysis of racial discrimination and difference. Oppressed, poor, displaced and disenchanted, many of Kim's Korean characters find solace in nationalist discourse, political activism, or even repatriation to North Korea. However, Kim reveals grave misgivings about these undertakings, depicting them as ineffectual means of escape from existential pain, that serve only to alienate Koreans from their actual subjective lived experiences. Kim's novels and essays, largely autobiographical, are introspective accounts of the psychological ramifications of being and feeling 'different', and question how one should face a harsh, unjust and sorrowful life. Unlike the majority of his peers, Kim distrusted the notion that appropriating a 'Korean' identity could remedy the difficulties and tribulations that existence generated. He urged a more rational and dispassionate resistance to racism that did not rely on ethnocentric or nationalist doctrine. He was highly knowledgeable about zainichi Korean affairs and critiqued prejudice in his novels and essays; but his portrayal of 'ethnic pride', whether Japanese or Korean, is censorious. Kim's heroes simply experience reality, rather than seek refuge in what the author depicts as ineffectual political or ethnic alliances or activities. Unfortunately, throughout his life Kim faced criticism for discounting ethnocentrism as a valid stratagem of resistance, and some link this to his 1985 suicide. 


\section{Kim Ha Gyong's「錯迷」Sakumei [Delusions]}

Kim Ha Gyong's 1971 novel Delusions is close to a memoir of its hero and first person narrator, Shin Junichi (Shin Sun Il), a character based on Kim. He is a rational but depressed physicist working in a lab at Sendai University, conducting experiments on complex enzymes. Delusions is both a present-tense dialogue between the main character and his alter ego, Tei Yōshin (Chong Yong Shin), as well as an internal monologue of the protagonist reminiscing about his past. With Tei's voice and Shin's unspoken thoughts, Kim delivers a succinct history of the Cold War as it affected Koreans both on the peninsula and in Japan; and illustrates the life stages of a second-generation Korean living in Japan between the 1950s and 1970s.

The key consideration of the hero, though, is not history, politics, or race; rather it is the existential predicament of 'starvation of the heart', and, specifically, his own. ${ }^{7}$ Despite his crushing cynicism, he demonstrates an unyielding commitment to finding a lasting solution - a will to live:

I feel that starvation in the heart... What is it I have to do? I really don't know. I cannot feel at peace, I cannot feel settled... Is it just me? If someone doesn't live to his potential he won't know his own value. Isn't it our duty to live to our own potential everyday? (Kim, H. G.: 179)

Throughout the novel, Kim calls attention to the prevalence of domestic violence in the hero's zainichi Korean community, intimating its causal role in the hero's ambivalence about his existence. The tormented hero can find no valid reason to continue living:

The worst things in the world were the fights between my father and mother. They were so bad, so horrific and sinister. They froze my soul. (Kim, H. G.: 182)

What reason was there to live? (Kim, H. G.: 193)

Throughout Delusions, Kim dispassionately dismisses political activism, or a turn to ethnicity, as the means for alleviating existential trauma. Kim believed that it was the unfortunate fate of zainichi Koreans to be coerced into 'repatriating' to North Korea, which promised a decent homeland to zainichi Koreans. ${ }^{8}$ Kim depicts the Repatriation Movement not as a commendation of North Korea but as a condemnation of Japan; one that would lead only to further misery for zainichi Koreans. His characterisation of the

\footnotetext{
7 A concept borrowed from Mori Ōgai, the well-known Meiji era physician, theorist, and man of letters.

${ }^{8}$ Repatriation is a misleading term as the tens of thousands of Koreans who left for the DPRK, from 1969 onwards, had been born in the ROK or in Japan and had hitherto never set foot in the DPRK.
} 
mass exodus was unprecedented, but would, sadly, prove correct; North Korea was not the 'heaven on earth' that most of Kim's peers had claimed it was:

(In Niigata at the pier) The older folks all looked beaten, like they'd given up. They had crossed the Korea Sea a few decades earlier to come here! ${ }^{9}$ What did they want? What had they felt then? What did they get? Nothing. They only found despair in Japan and now they had to go somewhere new and start again. You could see fear and doubt in their faces. (Kim, H. G.: 207)

Additionally, Kim's protagonist depicts it as a personal escape for his sister from her father's violence; and the following passage should also be understood as a condemnation of domestic violence:

Akiko wasn't going back to build a country. This was just a pretext. She was going to North Korea because she couldn't bear to stay in our miserable house one minute longer. It wouldn't have mattered what possible problems faced her in the DPRK, they were nothing compared to the problems she had here. At least that was what Akiko, at seventeen, thought. (Kim, H. G.: 204)

Kim's protagonist is only interested in how to mitigate his 'starvation of the heart'. Shin never considered political activism as a solution. ${ }^{10}$ For Shin, such a choice lacked credibility or the potential to remedy a veritable 'starvation of the heart', which is emotional, not political, in nature. Shin's 'starvation of the heart' was psychologically bound to his experience of abuse and neglect at home, and its resolution was therefore unrelated to political activism. Kim portrays starvation of the heart as a universal condition, which an individual's minority status merely compounds. Forbearance and endurance, as opposed to diversion and escapism, are necessary to face reality squarely. Kim's hero remains committed to the pursuit of salvation of the heart and of love simply because his mind has the power to conceptualise salvation of the heart and love. He chooses to believe in these abstract phenomena despite having never experienced them:

As long as I don't give up the search for the sapphire island it won't disappear. (Kim, H. G.: 179)

\footnotetext{
${ }^{9}$ The Korea Sea is known as the Japan Sea in Japan.

${ }^{10}$ In this way Kim's 1970s protagonist really looks more like a third- or fourth-generation literary character from texts published during the 1980s or 1990s. Kim may have truly represented the subaltern, for whom an interest in politics would have been a luxury. He stood alone amongst his zainichi Korean literary peers, during the early postwar decades, for his apolitical and non-ethnocentric stance.
} 


\section{Conclusion}

Minority literature in Japan, as in any nation, attempts to redress the imbalance created in social discourse that privileges majority and disregards minority voices. Reading zainichi Korean literature and engaging in cross-cultural exchanges promote a rich understanding of the Korean experience in Japan and of multiculturalism in Japan. During the course of my stay in Japan, under the auspices of the Japan Foundation, I carried out 140 interviews, mainly with zainichi Koreans but also with some Japanese. Many of the zainichi Koreans I interviewed told me, 'Most Japanese avoid discussing minority issues with us for fear of being blamed for the social ills that still plague us'. However, many Japanese told me that they 'did not ask zainichi Koreans questions about minority issues for fear of pointing out someone's "difference", an act which might confirm an individual's racialised identity or convey arrogance or pity'. Thus it seems that the cultural crossings I was able to make were, in some way, facilitated by my status as a third party - a daisansha - or an outsider. I find a similar phenomenon at work in Australia, my home away from home, where I have lived for thirteen years. For example, when I asked my Aboriginal friend, Delina, 'What was it like growing up as an Aborigine in the 1960s and 1970s and what is it like to be an Aborigine now?' she lamented, 'That is a good question that Anglo-Aussies rarely ask me.' The questions I posed - to zainichi Koreans or to my Aboriginal friend - and the answers I received did not reify racialised stereotypes, rather they exposed me to what scholar Karen Paley calls insider information'. Misunderstanding and fear seem to be the culprits in the paucity of cultural exchange that characterise majority-minority relations. Open-minded inquiry and dialogue are necessary to overcome cultural isolation.

I am extremely grateful to the Japan Foundation for funding my field research and for endorsing the broad goal of my doctoral mission, which is to play a role, however humble, in facilitating the entry of zainichi Korean literature - specifically by Kim Sok Pom, Lee Hoe Song and Kim Ha Gyong - into the world-literary canon. Increased recognition of zainichi Korean literature amongst Japanese and post-colonial studies scholars in Australia will go a long way to achieving that end. I hope the introduction I have offered here inspires New Voices readers to further explore zainichi Korean literature and engage in cross-cultural dialogue at every opportunity.

\section{References}

Boehmer, E., Colonial and Postcolonial Literature Migrant Metaphors (Oxford \& New York: Oxford University Press, 1995).

Kim, H. G., 'Sakumei' in Kim H. G. Kim Ha Gyong sakuhin shūsei (Tokyo: Sakuhinsha, 1971).

Kim, S. P., Karasu no shi (Tokyo: Kodansha, 1971). 
Lee, H. S., Kinuta wo Utsu Onna (Tokyo: Bungei Shunjū, 1972).

Nelson, B., 'The Woman Who Ironed Clothes' in McCann, D. R. (ed.), Black Crane: An Anthology of Korean Literature (Ithaca, New York: Cornell University, East Asia Papers No. 14, 1979).

Paley, K., 'Religious Skirmishes: When the Ethnic Outsider Cannot Hear “The Loudest Voice” in Meyer, M. J. (ed.), Literature and Ethnic Discrimination (Atlanta, Georgia: Rodopi, 1997), pp. 1-16.

Takeda, S., [Zainichi] toiu konkyo (Tokyo: Chikuma Gakugei Bunko, 1995). 